Economic Quarterly - Volume 101, Number 1-First Quarter 2015-Pages 5-21

\title{
The Financial Crisis: Toward an Explanation and Policy Response
}

Aaron Steelman and John A. Weinberg

$\mathrm{T}$ he financial market events since August 2007-and especially those after September 2008 - have raised a number of important issues. Some commentators have argued that these events demonstrate fundamental flaws in the market system, flaws that can be corrected only by large-scale intervention. The causes of the financial market turmoil are far from settled and may not be fully known for some time. This essay will offer one perspective. We will argue that, although there is some evidence of market failure, the current crisis does not represent a wholesale failure of financial markets. Instead, we will argue that the crisis stems from the difficulty of responding to large shocks, the roots of which are multifaceted, including past policy errors. While there are ways in which financial regulation can be improved, there is also a strong case to be made that the functioning of market discipline can be improved by constraining some forms of government intervention, especially those that dampen incentives by protecting private creditors from loss.

It will be useful to think of the essay as divided into the following components. First, what has happened in the financial markets. Second, why those events took place. Third, possible market imperfections that could produce turmoil in the financial markets and an assessment of the role they have played in this case. And, fourth, how policymakers should respond in these difficult and uncertain times.

- The authors are, respectively, director of publications, and senior vice president and director of research at the Federal Reserve Bank of Richmond. They would like to thank Bob Hetzel, Jeff Lacker, Ned Prescott, and John Walter for helpful comments and suggestions. The views expressed are those of the authors and not necessarily those of the Federal Reserve System. 
Again, it is important to note that the thesis offered is only tentative. Financial economists, no doubt, will examine this period for many years to come and debate the merits of competing explanations. In doing so, they will refine those ideas and come closer to a comprehensive understanding of what has occurred. This research, hopefully, will be more than an academic exercise. It should provide insights to financial market participants and policymakers so that similar events do not arise in the future.

\section{WHAT HAPPENED: A BRIEF TIMELINE}

In the first half of 2007, as the extent of declining home prices became apparent, banks and other financial market participants started to reassess the value of mortgages and mortgage-backed securities that they owned, especially those in the subprime segment of the housing market. In early August 2007, the American Home Mortgage Investment Corporation filed for Chapter 11 bankruptcy protection, prompting concern among financial market participants. At its August 10, 2007, meeting, the Federal Open Market Committee (FOMC) stated that in "current circumstances, depository institutions may experience unusual funding needs because of dislocations in money and credit markets. As always, the discount window is available as a source of funding." The following month, the FOMC lowered the federal funds rate 50 basis points to 4.75 percent, the first in a series of rate cuts that would ultimately bring the target to a range of 0 to 0.25 percent in December 2008 .

The autumn of 2007 saw increasing strains in a number of market segments, including asset-backed commercial paper, and banks also began to exhibit a reluctance to lend to one another for terms much longer than overnight. This reluctance was reflected in a dramatic rise in the London Interbank Offered Rate (LIBOR) at most maturities greater than overnight. LIBOR is a measure of the rates at which international banks make dollar loans to one another. Since that initial disruption, financial markets have remained in a state of high volatility, with many interest rate spreads at historically high levels.

In response to this turbulence, the Fed and the federal government have taken a series of dramatic steps. As 2007 came to a close, the Federal Reserve Board announced the creation of a Term Auction Facility (TAF), in which fixed amounts of term funds are auctioned to depository institutions against any collateral eligible for discount win-

dow loans. So while the TAF substituted an auction mechanism for the usual fixed interest rate, this facility can be seen essentially as an extension of more conventional discount window lending. In March 2008, the New York Fed provided term financing to facilitate the purchase of 
Bear Stearns by JPMorgan Chase through the creation of a facility that took a set of risky assets off the company's balance sheet. That month, the Board also announced the creation of the Term Securities Lending Facility (TSLF), swapping Treasury securities on its balance sheet for less liquid private securities held in the private sector, and the Primary Dealer Credit Facility (PDCF). These actions, particularly the latter, represented a significant expansion of the federal financial safety net by making available a greater amount of central bank credit, at prices unavailable in the market, to institutions (the primary dealers) beyond those banks that typically borrow at the discount window. ${ }^{1}$

Throughout the summer of 2008, the stability of the housing finance government-sponsored enterprises, Fannie Mae and Freddie Mac, came under increasing scrutiny. While their core businesses have historically been in the securitization of less risky, "conforming" mortgages, they had in recent years accumulated significant balance sheet holdings of less traditional mortgage assets. In September, both companies were placed in conservatorship by the newly created Federal Housing Finance Agency.

In the fall of 2008, financial markets worldwide experienced another round of heightened volatility and historic changes for many of the largest financial institutions. Lehman Brothers filed for Chapter 11 bankruptcy protection; investment banking companies Goldman Sachs and Morgan Stanley successfully submitted applications to become bank holding companies; Bank of America purchased Merrill Lynch; Wells Fargo acquired Wachovia; PNC Financial Services Group purchased National City Corporation; and the American International Group received significant financial assistance from the Federal Reserve and the Treasury Department.

On the policy front, the Federal Reserve announced the creation of several new lending facilities - including the Asset-Backed Commercial Paper Money Market Mutual Fund Liquidity Facility (AMLF), the Commercial Paper Funding Facility (CPFF), the Money Market Investor Funding Facility (MMIFF), and the Term Asset-Backed Securities Loan Facility (TALF), the last of which became operational in March 2009. The TALF was designed to support the issuance of assetbacked securities collateralized by student loans, auto loans, credit card loans, and loans guaranteed by the Small Business Administration, while also expanding the TAF and the TSLF. The creation of these programs resulted in a tremendous expansion of the Federal Reserve's balance sheet. Furthermore, Congress passed the Troubled Asset Re-

\footnotetext{
1 The term "bank" is used broadly to refer to all depository institutions-including banks, thrifts, and credit unions - with routine access to the discount window.
} 
lief Program (TARP) to be administered by the Treasury Department. And in February 2009, the president signed the American Recovery and Reinvestment Act, a fiscal stimulus program of roughly $\$ 789$ billion. $^{2}$

\section{WHY THE CRISIS?}

The proximate cause of the financial distress since 2007 has been the decline in the housing market, which imposed substantial losses on financial institutions and led to disruptions throughout the credit markets. These disruptions have spread to the real economy, leaving the United States in the midst of a significant recession and prompting many of the measures described earlier.

What caused the boom in the housing market and its subsequent decline? Again, the answers are not obvious and various explanations will need to be vetted by economists over time. While multiple factors likely contributed to the cycle, some of which we will discuss below, a key factor involves the risk-taking incentives facing market participants.

First, there were what could be called "fundamental" factors. From roughly 1995 to 2005, the U.S. economy experienced a significant increase in productivity growth and thus real household income. Insofar as households saw these conditions as likely to continue, they increased demand for housing and thus housing prices. Indeed, housing investment and prices continued to rise through the 2001 recession, unlike most postwar business cycles. Those gains in productivity and household income began to weaken in 2005 - and with it, consumers' ability to repay their loans. Another plausible explanation involves technological advances in retail credit delivery. As financial institutions were able to more efficiently gather information about potential borrowers, they were able to more carefully craft loans to a wider segment of the population. In retrospect, some of those decisions may have been suspect - but, again, insofar as lenders believed economic conditions would continue on the trajectory they were then following, there was good reason for financial institutions to expand lending to people who in the past may not have received mortgages. One might argue that both borrowers and lenders "overshot" or behaved irrationally. But, given the information available to them at the time, their behavior seems less like mania and more like the actions of reasonable, foresighted actors, who happened to make an error in judgment about future trends in economic conditions. In addition to what we may consider explana-

\footnotetext{
${ }^{2}$ For a comprehensive timeline of the financial crisis, see the Federal Reserve Bank of St. Louis' website, "The Financial Crisis: A Timeline of Events and Policy Actions," at http://www.stlouisfed.org/timeline/default.cfm.
} 
tions based on economic fundamentals, there were also a series of public policy decisions that probably fueled the housing boom to levels inconsistent with market conditions. First, the Federal Reserve pursued an accommodative monetary policy following the terrorist attacks of 2001. This was especially true in 2003 and 2004 when the target for the federal funds rate was held between 1 percent and 2 percent, as the economy began to rebound from the earlier brief recession. Such policy created an environment in which credit grew quite freely. ${ }^{3}$ Others have argued that beyond the effects of monetary policy, long-term interest rates were held down by a "global savings glut." 4 This may have heightened investors' interest in "reaching for yield" by taking on greater risks.

Moreover, in an effort to expand access to housing credit, especially for people at the lower end of the income distribution, Fannie Mae and Freddie Mac increased their purchases of subprime securities. ${ }^{5}$ Many of the underlying loans in these securities proved problematic and, as noted earlier, contributed to Fannie and Freddie being placed under federal conservatorship. Why have problems in the housing market caused substantial turmoil throughout the banking sector, leading many institutions to become more cautious about their current lending actions and investors to be cautious in their dealings with banks? There are at least three possible explanations, all having to do with uncertainty.

First, there is uncertainty about the aggregate magnitude of the losses financial institutions are likely to suffer. Many of the mortgages they issued are of relatively recent vintage, so how those borrowersand, in turn, the lenders - will fare is unclear. Also, the extent of mortgage defaults and foreclosures will depend on the size of the decline in house prices - an ongoing process as of this writing.

Second, financial market participants are unsure about the distribution of those losses. Mortgage risks were spread widely, through securitization and use of the insurance capabilities provided by credit derivative contracts. Thus, institutions are concerned about how their counterparties' mortgage-related losses will affect their own viability.

Third, there is policy uncertainty. After the onset of the crisis, the Federal Reserve and the Treasury took several actions to help stabilize the financial sector. However, these actions appeared to evolve on a case-by-case basis. Some institutions received support, while others did not, making it more difficult for market participants to discern the governing principles and to make predictions about future policy moves.

\footnotetext{
3 Taylor (2008).

${ }^{4}$ Bernanke (2005).

${ }^{5}$ Meltzer (2009).
} 
These institutions were already facing an uncertain economic environment, which contributed to relatively sparse lending opportunities.

Coupled with an uncertain public policy environment, it is not surprising that many have been hesitant to lend and that many have had trouble raising private capital.

Any narrative of this boom-and-bust cycle must take into account the risk-taking incentives of financial market participants. And, here, the role of the federal financial safety net is important. Many financial transactions take place under some form of government protection. Some protections are explicit - such as the guarantee offered to bank depositors. Arguably, such protection has reduced depositors' incentive to scrutinize the riskiness of their banks' lending practices and may have contributed to the crisis experienced by thrifts in the 1980s. In addition, it seems likely that market participants view the safety net to include more than simply those explicit guarantees. That is to say, many market participants may believe that there are implicit guarantees, which also affect their risk-taking behavior. ${ }^{6}$ For instance, there has long been a widely held notion that some financial institutions are simply "too big to fail." Such institutions are perceived to be essential to the functioning of domestic and often of international financial markets. As a result, these institutions and their creditors may assume that, should they encounter difficulties due to unwise lending practices, the public sector will respond to maintain their solvency. ${ }^{7}$

Such public-sector action might take several forms. It could involve direct lending to troubled firms by the Federal Reserve or the Treasury Department. Or it could take a less direct form, such as that which occurred in the case of Long-Term Capital Management (LTCM). The Federal Reserve helped to orchestrate a recapitalization of LTCM by its creditors. Had LTCM's creditors not taken action to keep the firm from bankruptcy, it is unclear how the Fed would have responded. But market participants might have reasonably assumed - given the Fed's interest in seeing LTCM survive - that explicit federal assistance would have been forthcoming. Further, the Fed's involvement signaled a concern about the possible systemic consequences of losses incurred by the large institutions that were exposed to LTCM. ${ }^{8}$

Given the presence of the federal financial safety net-both its explicit and implicit guarantees - what options do policymakers face?

\footnotetext{
${ }^{6}$ Walter and Weinberg (2002).

${ }^{7}$ Such protection does not extend to the financial sector only. Other industries, such as the airline and automobile industries, have also received government assistance in the past decade.

${ }^{8}$ Haubrich (2007).
} 
Some might argue that the moral hazard problems associated with a large federal financial safety net cannot be avoided, especially in rich, advanced countries. As a result, we must more stringently regulate those firms that may avail themselves to such protection to ensure that they are acting prudently and, hence, to protect the taxpayer. Indeed, one may be skeptical - or remain relatively agnostic - about the inevitability or desirability of the federal financial safety net, yet still argue that, given its presence, the current regulatory regime may need to remain intact or be strengthened. ${ }^{9}$

Such arguments are reasonable. However, additional regulation of financial markets would likely hamper innovation in that industry. An alternative approach is to seek to reduce the scope of explicit safety net protection - as well as creditors' expectations of implicit protection of firms deemed too big to fail. ${ }^{10}$ The presence of the federal financial safety net was not the sole cause of questionable risk-taking by financial institutions. ${ }^{11}$ But it likely altered those institutions' behavior and, hence, contributed to the current turmoil. Any future attempt to redesign financial regulation should be undertaken with an assessment of the safety net, including the desirability and feasibility of scaling back implicit protections. Attempting to restructure the regulatory landscape without taking into account the effects of the safety net is like "putting the cart before the horse." 12

In summary, the boom and subsequent decline in the housing market had numerous causes. In hindsight, private lenders and borrowers may have made some imprudent decisions. But they were acting on what they believed to be sound information about the current state of the economy and the path of future growth.

Also, the Federal Reserve kept interest rates low for a long period, which may have encouraged additional lending that exacerbated the crisis. In addition, the government-sponsored enterprises greatly expanded their portfolios, boosting the market for loans that have proved difficult for many borrowers to repay. Finally, the presence of the federal financial safety net likely encouraged institutions to take risks that they otherwise would have forgone. The decline in the housing market has sent shocks throughout the banking industry and related financial

\footnotetext{
${ }^{9}$ Edward (1999).

${ }^{10}$ Stern and Feldman (2004) argue that too-big-to-fail protection imposes net costs on society and that the problem has grown in severity over time.

${ }^{11}$ For instance, Diamond and Rajan (2009) argue that, over short periods of time, even vigilant creditors may have difficulty monitoring whether financial managers are engaged in excessive risk-taking, especially in the case of new products.

${ }^{12}$ Kareken (1983) used this analogy in the slightly different context of banking deregulation in the $1980 \mathrm{~s}$.
} 
institutions. Already, the Federal Reserve, the Treasury Department, and Congress have taken considerable actions to stem the financial crisis. Later, we will comment on those programs and consider how the Federal Reserve, in particular, should try to implement an "exit strategy" that will ultimately lead to the winding down of current lending facilities and to renewed focus on price stability.

\section{RATIONALES FOR PUBLIC-SECTOR CREDIT IN FINANCIAL CRISES}

Much of the public policy response to turmoil in financial markets over the last two years has taken the form of expanded lending by the Fed and central banks in other countries. The extension of credit to financial institutions has long been one of the tools available to a central bank for managing the supply of money - specifically, bank reserves - to the economy.

Indeed, discount window lending by the 12 Reserve Banks was the primary means for affecting the money supply at the time the Fed was created. Over time, open market operations, in which the Fed buys and sells securities in transactions with market participants, have become the main tool for managing the money supply. Lending became a relatively little-used tool, mainly accessed by banks with occasional unexpected flows into or out of their Fed reserve accounts late in the day. If such banks were to seek funding in the market, they would likely have to pay above-normal rates for a short-term (overnight) loan. In this way, the discount window became a tool for dampening day-to-day fluctuations in the federal funds rate. In 2006, average weekly lending by the Reserve Banks through the discount window was $\$ 59$ million.

Since the outset of the widespread market disruptions in the summer of 2007, the Fed has changed the terms of its lending to banks and created new lending facilities. In the first three quarters of 2008, weekly Fed lending averaged $\$ 132.2$ billion, and in the fourth quarter of the year, that figure rose to $\$ 847.8$ billion.

In some cases, lending in response to a crisis can be seen as an extension of the use of central bank credit as a tool for managing the money supply. But for much of the current crisis, the Fed has not used its lending in this way.

Even though lending rose sharply, the Fed's overall balance sheet, and therefore its supply of money to the economy, remained roughly unchanged until September 2008. Until that time, the Fed was "sterilizing," or offsetting, its lending growth with open market operations. This suggests that, at least initially, the aim of expanded Fed credit was not growth in the overall supply of money or liquidity to 
markets but rather the direction of money or liquidity to particular market segments deemed to be in the greatest need of support.

The use of sterilized lending in order to direct funding to institutions or markets is based on the belief that, at times, financial markets cannot properly function in directing funds to where they are needed the most. ${ }^{13}$ Like any argument about the need for or consequences of public-sector intervention in markets, this is a statement of economic theory. In discussions of the Fed's actions in the last two years, two theoretical concepts have stood out as reasons why markets might fail to effectively allocate funds among market participants - coordination problems and "firesale" prices.

The classic example of a coordination problem in a financial market is a bank run. When depositors have the right to take their funds out of the bank on demand, and when the bank uses these highly liquid liabilities to fund longer-term, illiquid assets, then the bank is fragile in the sense that a sudden demand by many depositors for their money could force the bank to liquidate some of its longer-term assets inefficiently. This fragility makes the bank subject to a run in which depositors demand their funds because they think other depositors are doing the same. In such a case, all depositors might be better off if they could coordinate their decisions and leave their money in the bank, saving the bank from the costs of inefficient liquidations. The inability to coordinate means that bank runs could conceivably cause even a solvent bank to fail. ${ }^{14}$

The key characteristic that makes runs possible is the maturity mismatch on a bank's balance sheet-funding long-term assets with short-term liabilities. In recent years, this feature has not been limited to traditional, commercial banking. The securitization of mortgages and other assets has brought with it a number of other types of this maturity transformation - asset-backed commercial paper, auction-rate securities, and the funding of investment banks' holdings of securities through overnight repurchase agreements. Most of these nonbank arrangements have come under stress at some point during the ongoing market turbulence.

The fragility that makes runs possible, however, is itself the result of choices made by market participants. The willingness to create a fragile balance sheet structure should depend on market participants' beliefs about what would happen in the event of a run-like event. And part of these beliefs should involve people's expectations about

\footnotetext{
${ }^{13}$ Goodfriend and King (1988) argue that with well-functioning markets to redistribute funds, open market operations are sufficient to provide liquidity to markets.

${ }^{14}$ Diamond and Dybvig (1983).
} 
public-sector actions in the event of a run. In particular, the likelihood of assistance in the form of government or central bank lending reduces the prospective private costs of a run and, on the margin, increases the incentive to engage in maturity transformation. This is an essential part of the moral hazard problem resulting from the federal financial safety net. ${ }^{15}$

Another important ingredient of the theory of runs is that the early liquidation of long-term assets is costly. If a bank is forced to sell an asset to meet its depositors' demands for funds, there must be a real loss compared to holding the asset to maturity. If all assets could be sold at a price equal to the expected, discounted present value of the ultimate returns, then depositors' demands could be met without loss, which in turn eliminates a depositor's incentive to run. In traditional banking, the possibility of a run comes from the notion that the bank would have to sell loans, for which the originating bank has an advantage in monitoring borrowers' performance and ensuring repayment. But in the recent episode, assets at the heart of maturity transformation increasingly have been asset-backed securities, for which there may be no particular advantage to the institution holding securities on its balance sheet. Indeed, such securities were envisioned as a way of making loans more "tradeable" by pooling together many loans into a security.

Through much of this episode of financial volatility, many commentators have argued that the prices observed on many types of assets, especially those related to housing, represent deviations from fundamental market value. The available prices are seen as firesale priceslower than fundamental value because many institutions have been or may be forced to sell their assets in attempts to repair their balance sheets. For such low prices to persist, there must be no patient market participants with the financial resources and knowledge necessary to profit from buying assets at artificially low prices. This suggests that either the fundamental shocks affecting financial markets were so pervasive as to compromise essentially all participants' financial positions or there is some incompleteness or segmentation that prevents those with financial resources from taking advantage of arbitrage opportunities. ${ }^{16}$

Theories of market imperfections that give rise to financial market disruptions in which prices deviate persistently from fundamentals might imply that targeted public-sector credit can im-

\footnotetext{
${ }^{15}$ Lacker (2008). See also Ennis and Keister (2007).

16 Allen and Gale (1998) describe the phenomenon of "cash in the market pricing" in a financial crisis.
} 
prove the functioning of the market. But matching conditions observed in actual markets to conditions in these theories is a difficult judgment.

Much of what we have observed is also consistent with a market in which significant fundamental shocks have greatly increased the uncertainty facing market participants. If policymakers have no better information than market participants about fundamental values as compared to market prices, then the ability of targeted public-sector intervention to improve market conditions is limited.

\section{PAST, CURRENT, AND FUTURE PUBLIC POLICY RESPONSES}

It is understandable that the Federal Reserve, the Treasury Department, and Congress were eager to act as the financial system began to face what many feared to be systemic risks. However, problems in the financial system have persisted in spite of these efforts and some of those resulting policies could create challenges of their own over time.

The most fundamental issue, of course, is moral hazard. How will current federal intervention affect the behavior of banks and investors in the future? That is, will the support that has been provided encourage financial institutions to engage in behavior that they otherwise would have eschewed? Basic economic theory suggests so: The more something is subsidized, the more that is likely to be provided. In this case, the "something" is leveraged risk-taking, leading to potentially imprudent lending. How large this effect will be is ultimately an empirical question. But it is important to note that even if all of the new lending facilities were eliminated as the economy and financial system recover, moral hazard will still be a problem. Market participants know that federal support was readily forthcoming during the current turmoiland most now would reasonably expect that such support will be there when the next turmoil occurs. Changing these expectations will be a long and hard process. In short, the Fed will need to regain credibility for not bailing out insolvent institutions - and as we know from our experience with monetary policy in the 1970s, such efforts to gain credibility can be long and difficult. ${ }^{17}$

The current situation, with a vastly expanded financial safety net, presents long-term challenges with respect to private-sector risk-taking and risk-management incentives. Even in the near term, the task of scaling back the safety net toward its pre-crisis status raises many

\footnotetext{
${ }^{17}$ Goodfriend and Lacker (1999) discuss how central banks could build a reputation for limiting their lending commitments, just as central banks acquired credibility for maintaining price stability.
} 
difficult questions. For instance, the extent to which the new lending facilities should be either eliminated or moved to the Treasury Department is a matter of debate. But, as a matter of governance and central bank independence, there is a strong argument that those facilities which target specific industries or credit markets should be handled first. The provision of subsidized credit - especially on a sustained basis - is a fiscal policy action. Depending on one's perspective, this may or may not be a desirable policy goal, but it is arguably not one that should be pursued by the central bank. Placing the administration and funding of such programs under the direction of the Treasury Department puts those programs more directly under congressional authority.

The conflation of the roles of the Federal Reserve and the Treasury Department during the current crisis could threaten the Fed's independence. The Federal Reserve's principal policy goal is to conduct monetary policy in pursuit of price stability and sustainable macroeconomic growth. That goal is much harder to pursue in a world where the Fed is also operating a number of lending facilities. In the near term, inflation does not appear to be a problem, certainly not relative to continued weakness in the real economy. But when the economy recovers, the Fed must have the flexibility to restrain monetary growth and prevent rising inflation. And the Fed's ability to exercise this vigilance will be enhanced if it can separate its credit policy activities from its management of the money supply. Expansion of Fed credit expands the monetary base by adding to reserves held by the banking system with the Fed. Indeed, from the beginning of September of 2008 through the end of the year, total reserves held at the Fed grew from close to $\$ 10$ billion to about $\$ 785$ billion. Other things equal, an expansion of the monetary base is stimulative. Such stimulus is generally warranted in a period of economic contraction. But when the economy recovers, the Fed will need to have the flexibility to remove the monetary stimulus brought about by an expanded base.

Fundamentally, the Fed must determine how it wishes to act as a lender of last resort. The Fed could benefit from heeding the advice of two classical economists, Henry Thornton and Walter Bagehot, who considered how the Bank of England could act effectively as the lender of last resort. The Thornton-Bagehot framework stressed six key points:

- Protecting the aggregate money stock, not individual institutions

- Letting insolvent institutions fail

- Accommodating only sound institutions 
- Charging penalty rates

- Requiring good collateral

- Preannouncing these conditions well in advance of any crisis so that the market would know what to expect. ${ }^{18}$

Current Federal Reserve credit policy has deviated from most if not all of these principles. Before the crisis, the Fed's lender of last resort activity functioned as a standing facility with fixed terms. Through the crisis, the Fed's approach has evolved and changed in numerous directions, including the direction of credit to particular market segments and institutions. Beyond winding down its many new lending vehicles, the Fed will need to make it clear to all market participants which principles it will follow during future crises. Reductions in the Fed's credit activities - even in the near term - do not need to result in monetary contraction, as those programs can be replaced by asset purchases.

This last point also applies to actions taken beyond those of the Federal Reserve. Public policies by all agencies must be well articulated and time consistent so that market actors can make rational plans regarding their financial and other business affairs. Arguably, such policy uncertainty did much to prolong the Great Depression in the United States. ${ }^{19}$ In addition, policymakers should be wary about the potential productivity-dampening effects of ill-considered fiscal and regulatory policies. There is some evidence that such policies slowed productivity in the United States during the $1930 \mathrm{~s}^{20}$ and in Japan during the 1990s. ${ }^{21}$ While, as noted earlier, the Federal Reserve should not be directly involved in appropriating funds, it is not beyond its bounds to offer thoughts on the relative efficiency of such programs pursued by the legislative and executive bodies.

\section{CONCLUSION}

The United States - and, indeed, the whole world - has experienced a significant financial and economic crisis since late 2007, and especially since September of 2008. The causes of that crisis are multifaceted and will require much future research. However, policymakers must act in real time on the best information available. It is not surprising that

\footnotetext{
${ }^{18}$ Humphrey (1989).

${ }^{19}$ Higgs (1997).

${ }^{20}$ Cole and Ohanian (2004).

${ }^{21}$ Hayashi and Prescott (2002) and Hoshi and Kashyap (2004).
} 
policymakers have taken a very active approach to the current crisis; after all, the costs of inaction were perceived to be quite large. The effects of those actions, just like the causes of the crisis, will no doubt continue to be the subject of much study and commentary for some time.

This episode has brought a number of particular questions to the forefront, questions that will be at the center of ongoing efforts to strengthen our financial system. Among those are questions regarding the possible sources of incentives for financial market participants to take excessive risks. One candidate discussed earlier involves the incentive effects of the federal financial safety net. The significance of this potential contributor to risk-taking lies in its implications for how we think about the role of Fed credit in ensuring financial stability. While the liberal provision of credit can cushion the effects of a crisis, expectation of such credit availability can dampen incentives to take actions that may limit the likelihood of a crisis. This tradeoff lies at the heart of any effort to design a set of policies that achieves a balance between the roles of government and market forces in disciplining the incentives of participants in our financial system.

\section{APPENDIX}

This timeline appeared in the original publication as a sidebar.

Summer 2007: Markets first respond on a large scale to concerns that mortgage-backed securities might significantly underperform expectations

August 10, 2007: Federal Reserve announces that it "will provide reserves as necessary" amidst strains in money and credit markets

September 18, 2007: FOMC lowers target federal funds rate 50 basis points to 4.75 percent, the first of a series of rate cuts

December 12, 2007: Fed announces creation of the Term Auction Facility (TAF), the first of several new tools designed to provide liquidity to markets

March 11, 2008: Fed creates Term Securities Lending Facility (TSLF), which trades banks' illiquid assets, including mortgage-backed securities, for liquid Treasury securities 
March 16, 2008: Fed creates Primary Dealer Credit Facility (PDCF), allowing it to lend to primary dealers for the first time

March 14-24, 2008: Fed announces it will provide term financing for JPMorgan Chase to purchase Bear Stearns by taking risky securities off Bear's balance sheet via the PDCF

September 7, 2008: Federal Housing Finance Agency (FHFA) places Fannie Mae and Freddie Mac in government conservatorship following increasing scrutiny over their soundness

September 15, 2008: Lehman Brothers files for Chapter 11 bankruptcy protection

October 3, 2008: President Bush signs into law the Emergency Economic Stabilization Act of 2008, establishing the $\$ 700$ billion Troubled Asset Relief Program (TARP)

November 25, 2008: Fed announces creation of the Term Asset-Backed Securities Loan Facility (TALF), supporting the issuance of assetbacked securities. Becomes operational in March 2009

November 25, 2008: Fed announces program to purchase direct obligations of Fannie Mae and Freddie Mac, and mortgage-backed securities backed by them. Purchases begin January 5, 2009

December 11, 2008: The Business Cycle Dating Committee of the National Bureau of Economic Research announces that the recession began in December 2007

December 16, 2008: FOMC votes to establish a range for the fed funds rate of 0 to 0.25 percent

\section{REFERENCES}

Allen, Franklin, and Douglas M. Gale. 1998. "Optimal Financial Crises." Journal of Finance 53 (4): 1,245-84.

Bernanke, Ben S. 2005. "The Global Saving Glut and the U.S. Current Account Deficit." Remarks before the Virginia Association of Economists, Richmond, Va. (March 10). 
Cole, Harold L., and Lee E. Ohanian. 2004. "New Deal Policies and the Persistence of the Great Depression: A General Equilibrium Analysis." Journal of Political Economy 112 (4): 779-816.

Diamond, Douglas W., and Philip H. Dybvig. 1983. "Bank Runs, Deposit Insurance, and Liquidity." Journal of Political Economy 91 (3): 401-19.

Diamond, Douglas W., and Raghuram G. Rajan. 2009. "The Credit Crisis: Conjectures About Causes and Remedies." Cambridge, Mass.: National Bureau of Economic Research Working Paper 14739 (February).

Edward, Franklin R. 1999. "Hedge Funds and the Collapse of Long-Term Capital Management." Journal of Economic Perspectives 13 (2): 189-210.

Ennis, Huberto M., and Todd Keister. 2007. "Bank Runs and Institutions: The Perils of Intervention." Federal Reserve Bank of Richmond Working Paper 07-02 (March).

Goodfriend, Marvin, and Robert G. King. 1988. "Financial Deregulation, Monetary Policy, and Central Banking." Federal Reserve Bank of Richmond Economic Review 74 (3): 3-22.

Goodfriend, Marvin, and Jeffrey M. Lacker. 1999. "Limited Commitment and Central Bank Lending." Federal Reserve Bank of Richmond Economic Quarterly 85 (4): 1-27.

Haubrich, Joseph G. 2007. "Some Lessons on the Rescue of Long-Term Capital Management." Federal Reserve Bank of Cleveland Policy Discussion Paper 19 (April).

Hayashi, Fumio, and Edward C. Prescott. 2002. "The 1990s in Japan: A Lost Decade." Review of Economic Dynamics 5 (1): 206-35.

Higgs, Robert. 1997. "Regime Uncertainty: Why the Great Depression Lasted So Long and Why Prosperity Resumed After the War." Independent Review 1 (4): 561-90.

Hoshi, Takeo, and Anil Kashyap. 2004. "Japan's Financial Crisis and Economic Stagnation." Journal of Economic Perspectives 18 (1): $3-26$.

Humphrey, Thomas M. 1989. "Lender of Last Resort: The Concept in History." Federal Reserve Bank of Richmond Economic Review 75 (2): 8-16.

Kareken, John H. 1983. "Deposit Insurance Reform or Deregulation Is the Cart, Not the Horse." Federal Reserve Bank of Minneapolis Quarterly Review 7 (2): Not numbered. 
Lacker, Jeffrey M. 2008. "Financial Stability and Central Banks." Remarks before the European Economics and Financial Centre, London, England (June 5).

Meltzer, Allan H. 2009. "The Global Financial Crisis of 2007-2009." American Enterprise Institute, manuscript (January).

Stern, Gary H., and Ron J. Feldman. 2004. Too Big to Fail: The Hazards of Bank Bailouts. Washington, D.C.: Brookings Institution Press.

Taylor, John B. 2008. "The Financial Crisis and the Policy Responses: An Empirical Analysis of What Went Wrong." Stanford University, manuscript (November).

Walter, John R., and John A. Weinberg. 2002. "How Large is the Federal Financial Safety Net?" Cato Journal 21 (3): 369-93. 